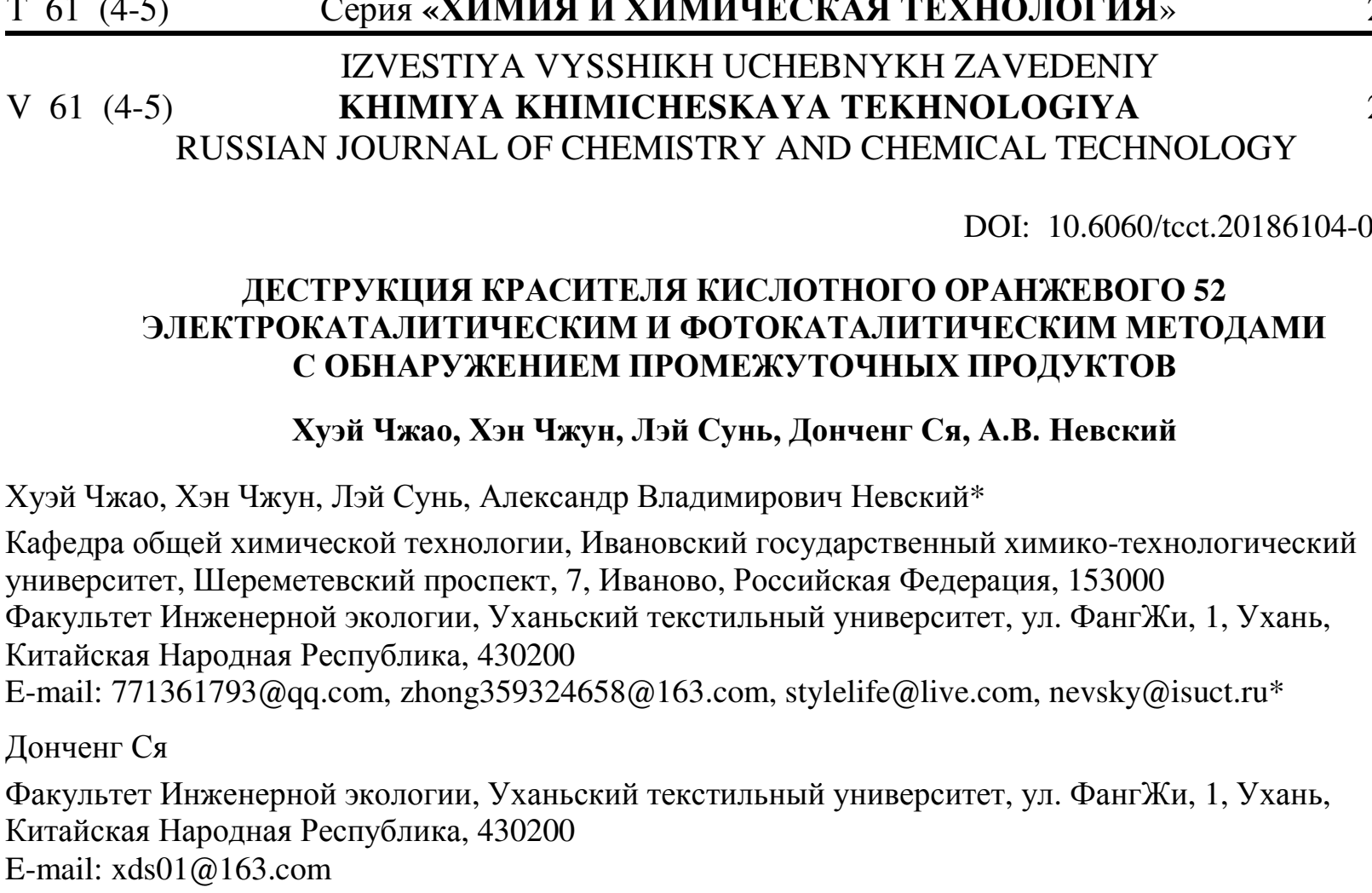

Изучена эффективность деструкции красителя кислотного оранжевого 52 в водных растворах при совмещении электрокаталитического и фотокаталитического процессов. Электрокаталитический и фотокаталитический методы на практике относят к высокоэффективным окислительным процессам (ВОП). При проведении фотокаталитического процесса изучали влияние дозы катализатора В и времени облучения на степень деструкции красителя. Нами было показано, что при обработке в оптимальных условиях электрокаталитическим методом с катализатором А модельных сточных вод, содержащих краситель кислотный оранжевый 52, эффективность обесцвечивания составила 95\% в видимой области спектра (464 нм) и 38,6\% в ультрафиолетовой области (270 нм), соответственно. При использовании комбинации электрокаталитического и фотокаталитического процессов с катализаторами А и В, эффективность удаления окраски может достигать 99,3\% (464 нм) и 91,5\% (270 нм), соответственно. В ходе реакции окисления образуется больиое количество продуктов с низкой молярной массой. Кроме того, полученные значения величин химического потребления кислорода (ХПК) и общего органического углерода (ООУ) свидетельствуют о том, что сочетание электрокаталитического и фотокаталитического методов обработки может значительно повысить способность к биологическому разложению красителя в целом. Было показано, что степень снижения величин ХПК и ООУ составила, соответственно, 54,3\% и 72,8\%. Промежсточные продукты реакции определяли методом электроспрей-ионизационной масс-спектрометрии (ESI-MS), что позволило в результате предложить механизм (путь) процесса деструкции красителя. Результаты работы могут быть полезными в качестве теоретической основы для проектирования эффективной ресурсосберегающей, технически эффективной и экономически обоснованной системы обработки сточных вод, содержацих труднобиоразлагаемые азокрасители.

Ключевые слова: высокоэффективные окислительные процессы, электрокаталитический метод, фотокаталитический метод, краситель кислоты оранжевый 52, деструкция красителя, механизм (путь) процесса деструкции 


\title{
ACID ORANGE 52 DYE DEGRADATION BY ELECTROCATALYTIC PLUS PHOTOCATALYTIC TECHNIQUE AND INTERMEDIATES DETECTION
}

\author{
Hui Zhao, Heng Zhong, Lei Sun, Dongsheng Xia, A.V. Nevsky
}

Hui Zhao, Heng Zhong, Lei Sun, Alexander V. Nevsky*

General Chemical Engineering Department, Ivanovo State University of Chemistry and Technology, Sheremetev Av., 7, Ivanovo, 153000, Russia

School of Environmental Engineering, Wuhan Textile University, 1 FangZhi Road, Wuhan, 430200, P. R. China E-mail: 771361793@qq.com, zhong359324658@163.com, stylelife@live.com,nevsky@isuct.ru*

Dongsheng Xia

School of Environmental Engineering, Wuhan Textile University, 1 FangZhi Road, Wuhan, 430200, P. R. China E-mail: xds01@163.com

The degradation efficiency of Acid Orange 52 dye in an aqueous solutions using the combination of electrocatalytic and photocatalytic processes has been studied. Electrocatalytic and photocatalytic methods in practice reckon among advanced oxidation processes (AOPs). The effect of catalyst $B$ dosage and irradiarion time on the rate of mentioned dye degradation was studied in the photocatalytic process. It was shown, that when Acid Orange 52 simulated dye wastewater was treated by electrocatalytic technique under optimal conditions with catalyst $A$, the decolorization treatment effect was $95 \%$ in visible part of light spectrum (464 $\mathrm{nm}$ ) and $38.6 \%$ in ultraviolet part $(270 \mathrm{~nm})$, respectively. When the combined electrocatalytic-photocatalytic technique was processed with catalysts $A$ and $B$, the color removal rate of dye could reach 99.3\% (464 $\mathrm{nm}$ ) and 91.5\% $(270 \mathrm{~nm})$, respectively. The large amount of products of small mole weight was formed in the course of oxidation reaction. Moreover, the obtained values of chemical oxygen demand (COD) and total organic carbon (TOC) witnessed, that the combination of electrocatalytic and photocatalytic processes could significantly improve the biodegradability of dye as a whole. It was shown, that the removal rate of $C O D$ and $T O C$, respectively, were $54.3 \%$ and $72.8 \%$. The reaction intermediates were determined by electrospray ionization-mass spectrometry (ESI-MS) analysis, and as a result, the probable degradation mechanism (pathway) has been proposed. The results of the work may be useful as theoretical bases for designing effective resource-saving, technically efficient and economically sound wastewater treatment systems, containing hardly biodegradable azo dyes.

Key words: photocatalytic oxidation, dye degradation, Acid Orange 52, degradation pathway, mineralization

Для цитирования:

Чжао Х., Чжун Х., Сунь Л., Ся Д., Невский А. В. Деструкция красителя кислотного оранжевого 52 электрокаталитическим и фотокаталитическим методами с обнаружением промежуточных продуктов. Изв. вузов. Химия и хим. технология. 2018. Т. 61. Вып. 4-5. С. 111-118

For citation:

Zhao H., Zhong H., Sun L., Xia D., Nevsky A.V. Acid Orange 52 dye degradation by electrocatalytic plus photocatalytic technique and intermediates detection. Izv. Vyssh. Uchebn. Zaved. Khim. Khim. Tekhnol. 2018. V. 61. N 4-5. P. 111-118

\section{INTRODUCTION}

The dye wastewater accounts for about $10 \%$ of the total amount of industrial waste water. The organic pollutants which it emits is one of the main sources of organic pollution in the environment [1]. Azo dyes are the most variety and the largest number of synthetic organic dyes. The vast majority of azo dyes are coupled from aromatic amines after diazotization and phenols, aromatic amines which have active methylene compounds.
Azo dyes wastewater has high chroma, complex composition and poor biodegradability, and direct discharge has great harm to environment and organism [2-4].

Advanced oxidation processes (AOPs) are one of the most effective methods to degrade organic contaminants. Electrochemical oxidation [5-6], photocatalytic oxidation [7], wet air oxidation [8-9], supercritical water oxidation [10], ozonation [11], and other integrated techniques [12] have been proposed as substitutes for the conventional treatment techniques. 
Among these AOPs, photocatalytic technology has shown good application prospects. It has demonstrated its efficiency in degrading a wide range of ambiguous refractory organics into readily biodegradable compounds, and eventually mineralized them to innocuous carbon dioxide and water.

Acid Orange 52 is a representative compound of Azo dyes and one of the often used acid dyes in the textile industry, and was selected for this study. The study was specifically focused at: the effect of photochemical catalyst B dosage, the illumination time period in photocatalytic process and intermediate products detection.

\section{EXPERIMENTAL}

\section{Materials}

Acid Orange $52\left(\mathrm{C}_{14} \mathrm{H}_{14} \mathrm{~N}_{3} \mathrm{SO}_{3} \mathrm{Na}\right)$ was purchased from Sinopharm Chemical Reagent Co., Ltd.

Fig. 1 shows the chemical structure of Acid Orange 52. As it shown in Fig. 2 there are two characteristic absorption wavelengths, $270 \mathrm{~nm}$ and $464 \mathrm{~nm}$, respectively. The $270 \mathrm{~nm}$ is the absorption peak of benzene ring, and the $464 \mathrm{~nm}$ is the absorption peak of the conjugated system of the two benzene rings and $-\mathrm{N}=\mathrm{N}-$.

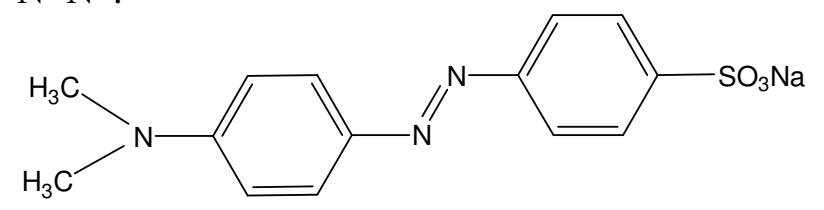

Fig. 1. Chemical structure of Acid Orange 52 dye molecule Рис. 1. Химическая структура молекулы красителя кислотного оранжевого 52

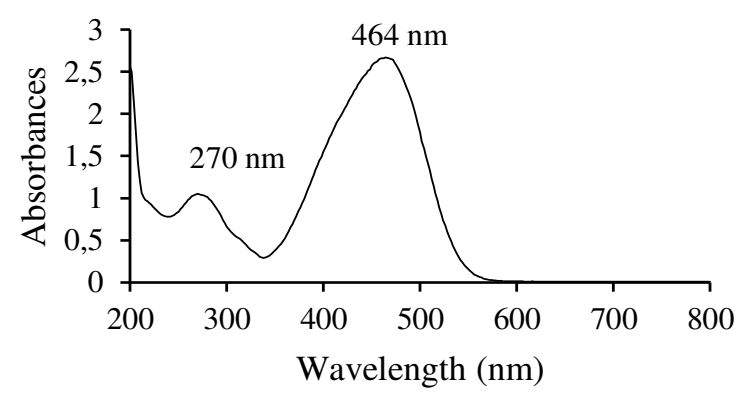

Fig. 2. Characteristic absorption wavelengths

Рис. 2. Характерные длины волн поглощения

All chemicals were of analytical grade if not noticed otherwise and were obtained from Sinopharm Chemical Reagent Co., Ltd. All chemicals were used as received without further purification. The sample solutions were prepared using deionized water (Aquapro, USA) throughout the experiments.

\section{Equipment}

The appliance for electrocatalytic degradation study and methodical peculiarities were described in our work [13]. The experimental facility for photocatalytic degradation study, as shown in Fig. 3, consists of mercury lamp (1) placed at distance from source to treated sample in a few centimeters, reactor itself (2) and magnetic stirrer (3), which was operated at constant stirring speed.

\section{Photocatalytic degradation procedures}

The batch photocatalytic experiment was carried out with volume of $50 \mathrm{ml}$ of simulated dye wastewater which has been treated before under optimal conditions of electrolysis with catalyst A. The magnetic stirrer was used to achieve the effective dispersion of photochemical catalyst B in photocatalytic degradation process. Before the beginning of photocatalytic reaction, the catalyst $B$ was stirred first during about $30 \mathrm{~min}$ in order to fully adsorb the dye.

In photocatalytic experiment the effects of photochemical catalyst B dosage and the illumination time on the dye degradation efficiency were investigated.

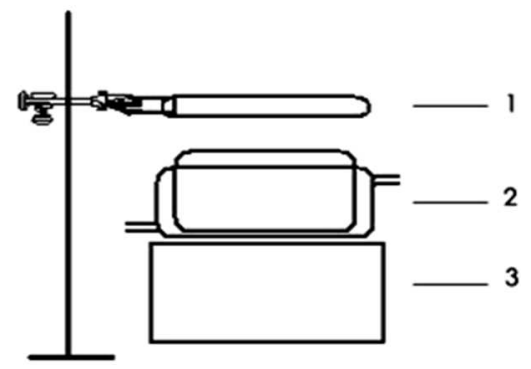

Fig. 3. The experimental setup for photocatalytic degradation study (1 - mercury lamp; 2 - reactor; 3 - magnetic stirrer) Рис. 3. Экспериментальная установка для исследования фотокаталитической деструкции (1 - ртутная лампа, 2 - реактор, 3 - магнитная мешалка)

\section{Analysis}

UV-VIS absorption spectra

To monitor the degradation process of Acid Orange 52, solution samples were taken out at predetermined time intervals and measured immediately on a UV-1201 spectrophotometer (Beijing Rayleigh Analytical Instrument Co., Ltd.) under the Characteristic absorption wavelength $(270 \mathrm{~nm}, 464 \mathrm{~nm})$ to record the temporal UV-VIS spectral variations of the dye. The related reaction progress was monitored using the UVVIS absorption spectra of Acid Orange 52, which was calculated from the following equation (percentage of decolorization):

$$
\mathrm{A} \%=\left(\mathrm{C}_{0}-\mathrm{C}_{\mathrm{t}}\right) / \mathrm{C}_{0} \cdot 100 \%
$$

Where $C_{t}$ is the absorbance at $270 \mathrm{~nm}$ and 464 $\mathrm{nm} \mathrm{nm}$ for Acid Orange 52 at reaction time $\mathrm{t}$ and $\mathrm{C}_{0}$ is the related initial absorbance.

Chemical oxygen demand (COD) and total organic carbon (TOC) determination

To monitor the properties of Acid Orange 52 biodegradation, solution samples were taken out at predetermined time intervals and COD and TOC values 
were measured immediately by using the relevant standard test procedures of People's Republic of China (COD:HJ/T399-2007; TOC:HJ/T104-2003) - the COD digestion instrument (Lovibond ET125SC, Qingdao $\mathrm{Xu}-\mathrm{Yu}$ Environmental Technology Co. Ltd.) and the TOC analyzer (Multi N/C 2100, Germany Jena Analytical Instrument Co., Ltd.). The related removal efficiency was calculated from the following equations:

$$
\begin{aligned}
& \mathrm{COD} \%=\left(\mathrm{COD}_{0}-\mathrm{COD}_{\mathrm{t}}\right) / \mathrm{COD}_{0} \cdot 100 \% \\
& \mathrm{TOC} \%=\left(\mathrm{TOC}_{0}-\mathrm{TOC}_{\mathrm{t}}\right) / \mathrm{TOC}_{0} \cdot 100 \%
\end{aligned}
$$

Where CODt and TOCt are the monitoring data under different reaction conditions for Acid Orange $52, \mathrm{COD}_{0}$ and $\mathrm{TOC}_{0}$ are the related initial data.

\section{Mass spectrometry method}

The intermediate products in the course of Acid Orange 52 degradation process were analyzed by mass spectrometry method. The experiment was performed at an Esquire LC-ion trap mass spectrometer (Bruker Daltonics, Bremen, Germany) equipped with an orthogonal geometry ESI source. Nitrogen was used as the drying ( $3 \mathrm{l} / \mathrm{min}$ ) and nebulizing (6 psi) gas at $300{ }^{\circ} \mathrm{C}$. The spray shield was set to $4.0 \mathrm{kV}$ and the capillary cap was set to $4.5 \mathrm{kV}$. Scanning was performed from 100 to $500 \mathrm{~m} / \mathrm{z}$ in the standard resolution mode at a scan rate of $13 \mathrm{kDa} / \mathrm{s}$.

\section{RESULTS AND DISCUSSION}

As it was shown by us earlier [13], that when Acid Orange 52 simulated dye wastewater was treated by electrocatalytic technique under optimal conditions $\left(\mathrm{C}_{\mathrm{dye}}=100 \mathrm{mg} / \mathrm{L}, \mathrm{U}=20 \mathrm{~V}, \mathrm{pH}=6, \mathrm{t}=50 \mathrm{~min}\right)$ with catalyst A, the decolorization treatment effect was $95 \%$ in visible part of light spectrum (464 nm) and 38.6\% in ultraviolet part $(270 \mathrm{~nm})$, respectively. And then this dye wastewater has been treated further by the photocatalytic method.

The effect of different reaction conditions on photocatalytic process

To evaluate the activities of different systems, the dye wastewater, which has been treated before by the electrocatalytic treatment system with catalyst A, was treated: 1) by photochemical catalyst $\mathrm{B}$ alone process, 2) by ultraviolet lamp irradiation alone process and 3) by photochemical catalyst B plus ultraviolet lamp irradiation combined processes. The reaction time period for wastewater sample treatment under stirring was about $30 \mathrm{~min}$ for fully dye adsorption on the catalyst B and for a more complete photocatalytic process.

As shown in Fig. 4, in the cases of catalyst B adsorption alone process, ultraviolet lamp irradiation alone process, and catalyst B plus ultraviolet lamp irradiation process, the effect of the treatment was greatly improved. Particularly, the treatment effect of the characteristic absorption wavelength in the ultraviolet spectra part was improved significantly. The characteristic absorption wavelength of ultraviolet spectra part almost disappeared. The characteristic absorption peak degradation speed is in order $464 \mathrm{~nm}>270 \mathrm{~nm}$. As it was discussed earlier [13], the electrocatalytic reaction first destroys the conjugated system of two benzene rings and $-\mathrm{N}=\mathrm{N}-$, resulting in obvious decoloration of the solution. Then the benzene ring structure is destroyed in the course of photocatalytic process. The structure of benzene ring in the molecule is more stable and more difficult to degrade, but can be completely degraded after the photocatalytic reaction.

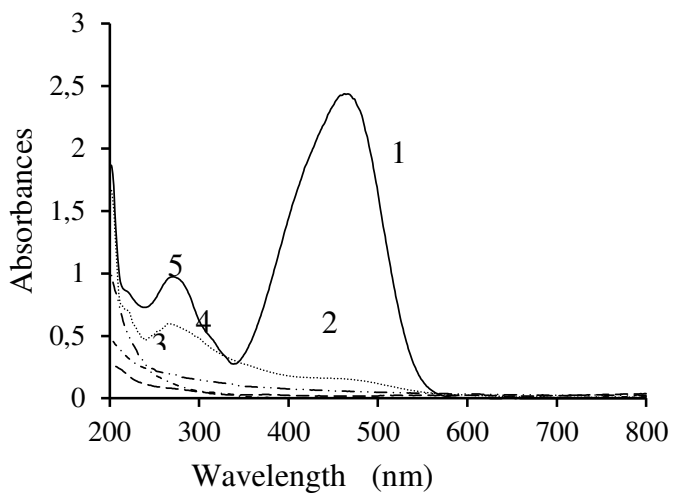

Fig. 4. Dye degradation process under different conditions: 1 - untreated simulated wastewater containing the dye; 2 - electrocatalytically treated wastewater with catalyst A; 3 - ultraviolet irradiation alone; 4 - catalyst B alone; 5 - catalyst B plus ultraviolet irradiation

Рис. 4. Процесс деструкции красителя при различных условиях: 1 - необработанная модельная сточная вода, содержащая краситель; 2 - электрокаталитически обработанная сточная вода в присутствии катализатора А; 3 - только ультрафиолетовое облучение; 4 - только присутствие катализатора В; 5 - при-

сутствие катализатора В плюс ультрафиолетовое облучение

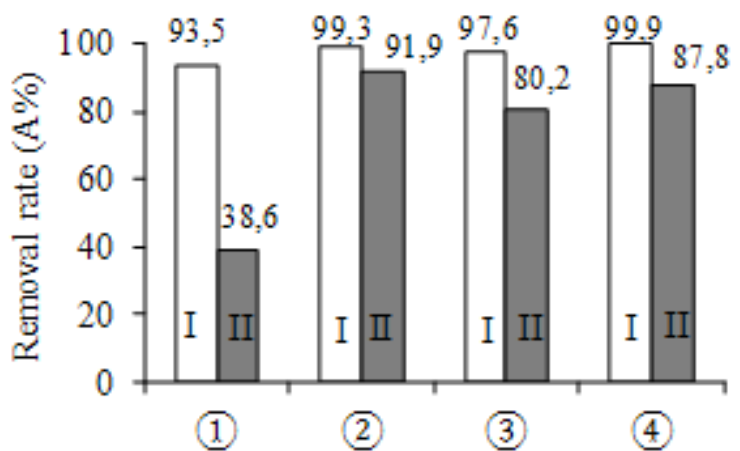

Fig. 5. Color removal rate of the dye's wastewater under different conditions: 1 - electrocatalytically treated wastewater with catalyst A; 2 - ultraviolet irradiation alone; 3 - catalyst $\mathrm{B}$ alone; 4 - catalyst B plus ultraviolet irradiation; I - $464 \mathrm{~nm}, \mathrm{II}-270 \mathrm{~nm}$ Рис. 5. Эффективность обесцвечивания сточных вод, содержащих краситель, при различных условиях: 1 - электрокаталитически обработанная сточная вода в присутствии катализатора А; 2 - только ультрафиолетовое облучение; 3 - только присутствие катализатора В; 4 - присутствие катализатора В плюс ультрафиолетовое облучение; I - 464 нм, II - 270 нм 
Fig. 5 illustrates the color removal rate of the dye's wastewater under different conditions. The dye degradation under ultraviolet irradiation alone is the best. There may be two reasons of this phenomenon. Firstly, it maybe because of small catalyst B activity for the degradation of Acid Orange 52 in this photodegradation system. Secondly, the amount of catalyst B maybe insufficient and does not reflect the catalytic effect.

The degree of mineralization of the Acid Orange 52 solution can be characterized by the removal rate of COD and TOC values of the dye wastewater. The data, regarding COD and TOC removal rate of the dye's wastewater under different conditions are shown in Fig. 6. The removal rates, caused by ultraviolet irradiation alone are the best, especially the degradation in the UV spectra part. As combined with the UV-Vis data, it can be concluded that the electrocatalytic reaction is the main decolorization stage of the dye, and the ultraviolet irradiation initiate the reaction of deep degradation. Catalyst B provide the increase in TOC removal rate of the dye's wastewater. Decolorization stage means, that the conjugated structure, which is chargeable for chromophore group of macromolecules, is destroyed to produce intermediates. This process has significant discoloring effect, but COD and TOC removal rates are relatively low. With the help of subsequent photo-degradation stage, the other structures and intermediates of the dye are further degraded to produce small molecular substances, which leads to the increase of COD and TOC removal rate.

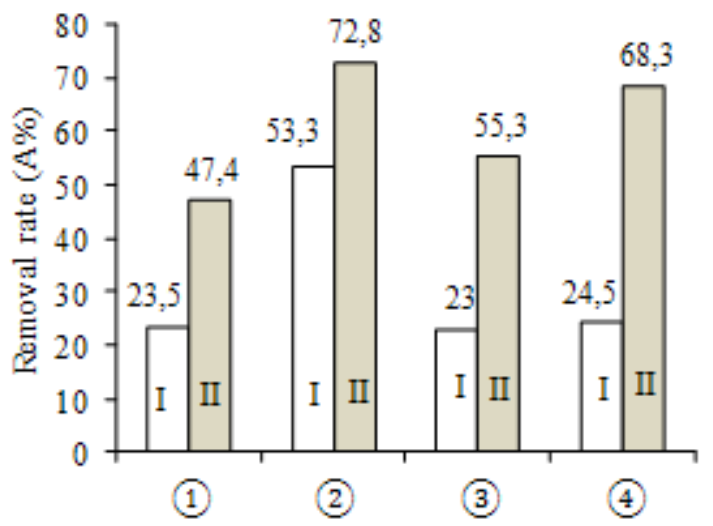

Fig. 6. COD (I) and TOC (II) removal rate of the dye's wastewater under different conditions: 1 - electrocatalytically treated wastewater with catalyst A; 2 - ultraviolet irradiation alone; 3 - catalyst B alone; 4 - catalyst B plus ultraviolet irradiation

Рис. 6. Эффективность снижения величин ХПК (I) и ООУ (II) в сточных водах, содержащих краситель, при различных условиях: 1 - электрокаталитически обработанная сточная вода в присутствии катализатора А; 2 - только ультрафиолетовое облучение; 3 - только присутствие катализатора В; 4 - присутствие катализатора В плюс ультрафиолетовое облучение.
The reason why the organic matter is easily degraded in the presence of UV irradiation is as follows. The ultraviolet irradiation resulted in a large amount of highly active $\bullet \mathrm{OH}$ particles and the oxidation of treated sample is improved. tion system

The effect of catalyst $B$ dosage in the illumina-

In order to verify the effect of the catalyst B in the illumination system, the effect of the amount of catalyst on the treatment effect was investigated. The results are shown in Fig. 7. Experimental conditions were as: $\mathrm{I}_{(254 \mathrm{~nm})}=37.9 \cdot 10^{3} \mu \mathrm{w} / \mathrm{cm}^{2}, \mathrm{t}=30 \mathrm{~min}$.

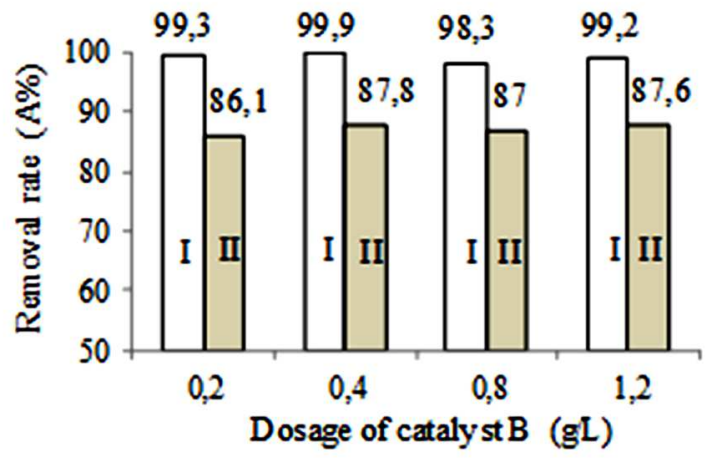

Fig. 7. Effect of catalyst B dosage on the dye degradation efficiency; I - $464 \mathrm{~nm}$, II - $270 \mathrm{~nm}$

Рис. 7. Влияние дозы катализатора В на эффективность деструкции красителя; I - 464 нм, II - 270 нм

The analysis of characteristic absorption wavelengths of the dye and the removal rates values witness, that the amount of catalyst B has small effect on the process. The increase of catalyst B amount did not improve the removal rate under ultraviolet irradiation. This indicates that the role of catalyst B in photo-degradation system in this case of dye's nature is small.

\section{Effect of illumination time}

The effect of illumination time on the dye degradation process without catalyst B was investigated by us. Fig. 8 illustrates these results.

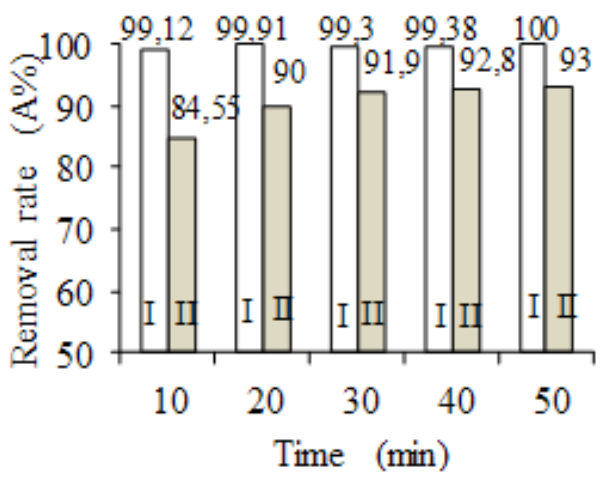

Fig. 8. Effect of irradiation time on the dye degradation efficiency; I - $464 \mathrm{~nm}, \mathrm{II}-270 \mathrm{~nm}$

Рис. 8. Влияние времени облучения на эффективность деструкции красителя; I - 464 нм, II - 270 нм 
Within period of time $30 \mathrm{~min}$, the removal rate increased with the increase of light exposure time. After $30 \mathrm{~min}$, the effect of irradiation time on the removal effect was minimal.

Mass spectrometric analysis of the degradation intermediates

The direct-infusion electrospray ionization mass spectrometry (ESI-MS), which is the advanced technology for detection and identification of reactants, products, and intermediates in solution $[14,15]$, was applied by us to screen for intermediate products in the course of Acid Orange 52 degradation with electrocatalytic-photochemical system. With the help of such mass spectra analysis, it was possible to deduce the proposed mechanism (pathway) of electrocatalyticphotochemical degradation of Acid Orange 52 dye. There are some papers in literature [16-23], devoted to the determination of reaction products in conditions, analogous to those, considered in our work. But the authors proposed various degradation pathway mecha-
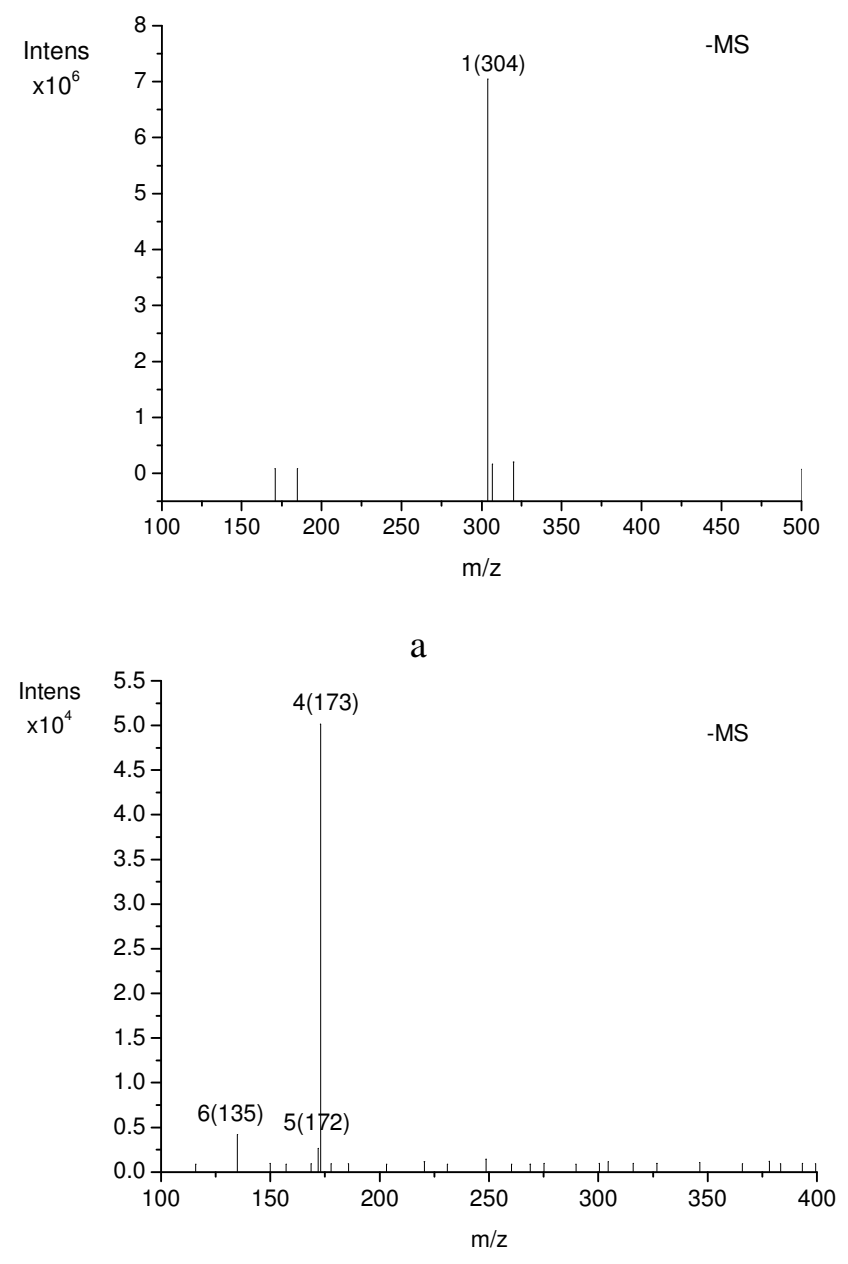

c nisms and, sometimes, it's difficult to find out any regularity in experimental results interpretation.

Fig. 9 displays the representative spectra in the negative ion model in the course of electrocatalyticphotochemical process. The molecular weight of Acid Orange 52 dye was 327 with the structure shown in Fig. 1, and in aqueous solution the $\mathrm{C}_{14} \mathrm{H}_{14} \mathrm{~N}_{3} \mathrm{SO}_{3} \mathrm{Na}$ groups in the dye will dissociate into $\mathrm{C}_{14} \mathrm{H}_{9} \mathrm{BrN}_{2} \mathrm{O}_{4}$, and then dissociate into $\mathrm{C}_{14} \mathrm{H}_{8} \mathrm{BrN}_{2} \mathrm{O}_{4}{ }^{-}$and $\mathrm{H}^{+}$ions. At the beginning of the reaction (Fig. 9, a), an intense ion of $\mathrm{m} / \mathrm{z} 304$ corresponding to Acid Orange $52[\mathrm{M}-\mathrm{H}]^{-}$ were observed as expected. After $50 \mathrm{~min}$ when the Acid Orange 52 dye solution was treated only by electrocatalytic process, the intensity of Acid Orange 52 at $\mathrm{m} / \mathrm{z} 304$ decreased significantly, indicating that it was degraded into some intermediate products. The signal peaks at m/z 276 and 290 showed up (Fig. 9, b). And after 30 min when the Acid Orange 52 dye solution was further treated by photochemical process, the intensity of Acid Orange 52 dye at $\mathrm{m} / \mathrm{z} 304$ disappeared. The signal peaks at $\mathrm{m} / \mathrm{z} 135,172$, and 173 showed up.

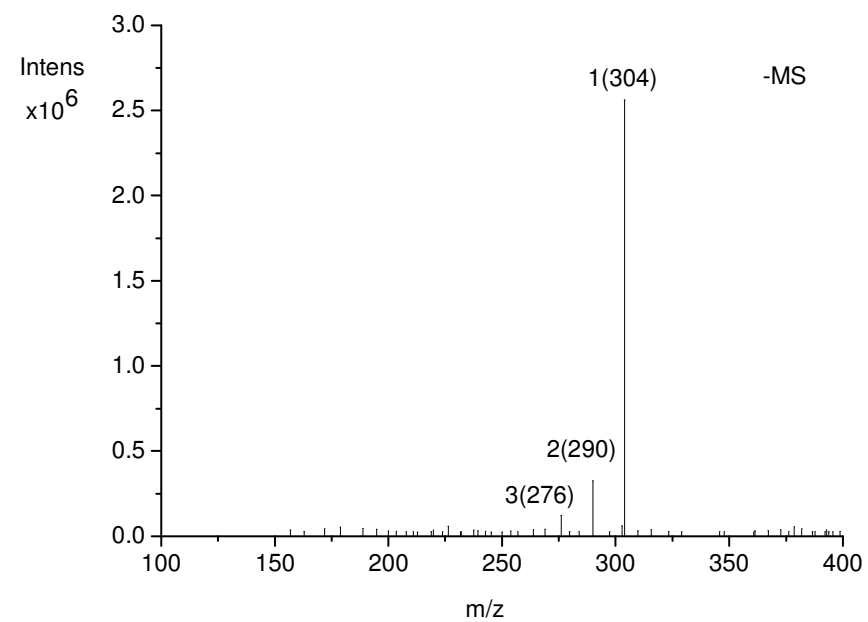

b

Fig. 9. ESI (-) mass spectra of Acid Orange 52 dye solution (the optimal conditions of electrocatalytic treatment with catalyst A: $\mathrm{C}_{\text {dye }}=100 \mathrm{mg} / \mathrm{l}, \mathrm{U}=20 \mathrm{~V}, \mathrm{pH}=4, \mathrm{t}=50 \mathrm{~min}$; the optimal conditions of photocatalytic treatment with catalyst $\mathrm{B}: \mathrm{t}=30 \mathrm{~min}$, I $\left.(254 \mathrm{~nm})=37.9 \cdot 10^{3} \mu \mathrm{w} / \mathrm{cm}^{2}\right) \mathrm{a}-$ at the beginning of the reaction; b - electrocatalytically treated wastewater with catalyst A; c - electrocatalytically treated wastewater with catalyst $\mathrm{A}$ and then photocatalytically treated with catalyst B under ultraviolet irradiation.

Рис. 9. ESI (-) масс-спектры с отрицательной ионизацией раствора красителя кислотного оранжевого 52 (оптимальные условия электрокаталитической обработки в присутствии катализатора А: $\mathrm{C}_{\text {dyе }}=100$ мг/л, $\mathrm{U}=20 \mathrm{~V}, \mathrm{pH}=4, \mathrm{t}=50$ мин; оптимальные условия фотокаталитической обработки в присутствии катализатора B: $\mathrm{t}=30$ мин, I $\left.(254 \mathrm{~nm})=37,9 \cdot 10^{3} \mu \mathrm{w} / \mathrm{cm}^{2}\right)$ a) - в начале реакции; b) - электрокаталитически очищенные сточные воды с катализатором А; c) - электрокаталитически очищенные сточные воды с катализатором А, с последующей фотокаталитической обработкой с катализатором В при ультрафиолетовом облучении 


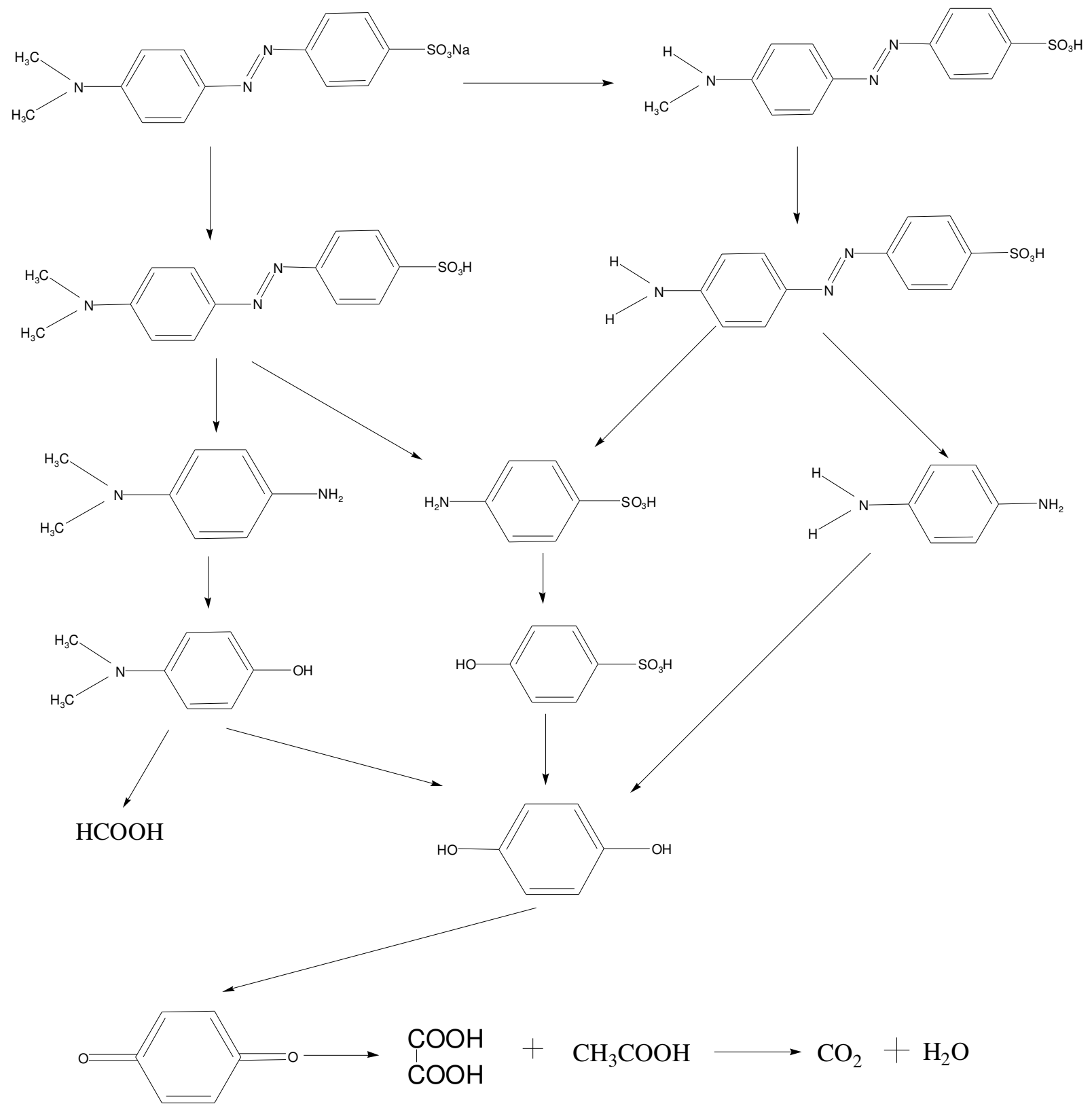

Fig. 10. The scheme of proposed degradation mechanism (pathway) of Acid Orange 52 dye by combination of electrocatalytic and photocatalytic processes

Рис. 10. Схема предлагаемого механизма (пути) процесса деструкции красителя кислотного оранжевого 52 комбинацией электрокаталитического и фотокаталитического процессов

With the reaction proceeding Acid Orange 52 dye was further degraded into simple carboxylic acids and $\mathrm{CO}_{2}$. As a result, the probable degradation mechanism (pathway) has been proposed by us as the reactions sequence for degradation of Acid Orange 52 dye by electrocatalytic-photochemical treatment. It is shown in Fig. 10.

\section{CONCLUSION}

It was shown an effective degradation rate of Acid Orange 52 dye under optimal processes condi- tions when the combined electrocatalytic-photocatalytic technique was used. The dye removal efficiency reaches $99.3 \%$ (in visible light spectrum) and $91.5 \%$ (in UV-light spectrum), respectively.

The ESI-MS analysis of reaction intermediates has shown that the chromophore group of the dye can be oxidized and degraded. And the resulting aromatic products can be destructed further and degraded into small molecular weight products, eventually into simple carboxylic acids, carbon dioxide and water. The Acid Orange 52 dye degradation mechanism (path- 
way) by combination of electrocatalytic and photocatalytic processes was proposed.

We believe, that the results of this study may be useful as theoretical grounds for designing an effective resource-saving, technically efficient and economically sound water management systems [24], which use in their technology the hardly biodegradable substances, such as azo dyes.

\section{REFERENCES ЛИТЕРАТУРА}

1. Wang K., Chen Y.X., Ye F.X. Degradation of Dye Pollutants on $\mathrm{SiO}_{2}$-Supported $\mathrm{TiO}_{2}$ Photocatalyst under Visible Light Irradiation. J. Catalysis. 2004. V. 25. N 12. P. 931-936.

2. Huang Y. Methods and development of azo dye wastewater treatment. J. Yi bin University. 2007. V. 6. P. 54-57.

3. Novotný Č., Dias N., Kapanen A., Malachová K., Vándrovcová M., Itävaara M., Lima N. Comparative use of bacterial, algal and protozoan tests to study toxicity of azo and anthraquinone dyes. Chemosphere. 2006. V. 63. P. 1436-1442.

4. All'egre C., Moulin P., Maisseu M., Charbit F. Treatment and reuse of reactive dyeing effluents. J. Membr. Sci. 2006. V. 269. P. 15-34.

5. Rajkumar D., Song B.J., Kim J.G. Electrochemical degradation of Reactive Blue 19 in chloride medium for the treatment of textile dyeing wastewater with identification of intermediate compounds. Dyes Pigments. 2007. V. 72. P. 1-7.

6. Mohan N., Balasubramanian N., Ahmed Basha C. Electrochemical oxidation of textile wastewater and its reuse. Hazard Mater. 2007. V. 147. P. 644-651.

7. Rizzo L., Koch J., Belgiorno V., Anderson M.A. Removal of methylene blue in a photocatalytic reactor using polymethylmethacrylate supported $\mathrm{TiO}_{2}$ nanofilm. Desalination. 2007. V. 211. P. 1-9.

8. Lee D.K., Cho I.C., Lee G.S., Kim S.C., Kim D.S., Yang Y.K. Catalytic wet oxidation of reactive dyes with $\mathrm{H}_{2} / \mathrm{O}_{2}$ mixture on Pd-Pt $/ \mathrm{Al}_{2} \mathrm{O}_{3}$ catalysts. Purif. Technol. 2004. V. 34. P. 43-50.

9. Liu Y., Sun D.Z. Development of $\mathrm{Fe}_{2} \mathrm{O}_{3}-\mathrm{CeO}_{2}-\mathrm{TiO}_{2} / \mathrm{Al}_{2} \mathrm{O}_{3}$ as catalyst for catalytic wet air oxidation of methyl orange azo dye under room condition. Appl. Catal. B Environ. 2007. V. 72. P. 205-211.

10. Sogut O., Akgun M. Treatment of textile wastewater by SCWO in a tube reactor. Supercrit. Fluid. 2007. V. 43. P. 106-111.

11. Oguz E., Keskinler B., Celik Z. Ozonation of aqueous Bomaplex Red CR-L dye in a semi-batch reactor. Dyes Pigments. 2005. V. 64. P. 101-108.

12. Zainal Z., Lee C.Y., Hussein M.Z., Kassim A., Yusof N.A. Electrochemical-assisted photodegradation of mixed dye and textile effluents using TiO2 thin films. Hazard Mater. 2007. V. 146. P. 73-80.

13. Hui Zhao, Heng Zhong, Lei Sun, Dongsheng Xia, Nevsky A.V. Acid Orange 52 dye degradation efficiency by electrocatalytic method. Izv. Vyssh. Uchebn. Zaved. Khim. Khim. Tekhnol. 2018. V. 61. N 3. P. 64-69 (in Russian).

Hui Zhao, Heng Zhong, Lei Sun, Dongsheng Xia, Nevsky A.V. Эффективность деструкции красителя кислотного оранжевого 52 электрокаталитическим методом. Изв. вузов. Химия и хим. технология. 2018. Т. 61. Вып. 3. Р. 64-69.

14. Lopez C, Valade A G, Combourieu B. Mechanism of enzymatic degradation of the azo dye Orange II determined by ex situ $1 \mathrm{H}$ nuclear magnetic resonance and electrospray ionization-ion trap mass spectrometry. Analytical Biochemistry. 2004. V. 335. N 1. P. 135-149.

15. Urzedo de A.P.F.M., Nascentes C.C., Diniz M.E.R., Catharino R.R., Eberlin M.N., Augusti R. Indigo carmine degradation by hypochlorite in aqueous medium monitored by electrospray ionization mass spectrometry. J. Mass Spectrometer. 2007. V. 21. P. 1893-1899.

16. Liu X.L., Yan Y., Da Z.L. Significantly enhanced photocatalytic performance of $\mathrm{CdS}$ coupled $\mathrm{WO}_{3}$ nanosheets and the mechanism study. J. Chem. Eng. J. 2014, V. 241. P. 243-250.

17. Guo X.Y., Chen C.F., Song W.Y. CdS embedded $\mathrm{TiO}_{2}$ hybrid nanospheres for visible light photocatalysis. J. Molecul. Catal. A Chem. 2014. 387(6). P. 1-6.

18. Wang S.M., Guan Y., Wang L.P. Fabrication of a novel bifunctional material of $\mathrm{BiOI} / \mathrm{Ag}_{3} \mathrm{VO}_{4}$ with high adsorptionphotocatalysis for efficient treatment of dye wastewater. J. Appl. Catal. B: Environm. 2015. V. 25. P. 448-457.

19. Haque F., Vaisman E., Langford C.H., et al. Preparation and performance of integrated photocatalyst adsorbent (IPCA) employed to degrade model organic compounds in synthetic wastewater. J. Photochem. Photobiol. A: Chem. 2005. V. 169. N 1. P. 21-27.

20. Telke A., Kalyani D., Jadhav J. Kinetics and mechanism of Reactive Red 141 degradation by a bacterial isolate Rhizobium radiobacter MTCC 8161. Acta Chimica Slovenica. 2008. V. 55(2). P. 320.

21. Pandey A., Singh P., Iyengar L. Bacterial decolorization and degradation of azo dyes. J. Internat. Biodeteriorat. Biodegrad. 2007. V. 59. N 2. P. 73-84.

22. Tian Chang-Shun, Liu Zu-Wen. Quantitative relationship between molecular structure of azo dyes and their decolorization performance. J. Industrial Water \& Wastewater. 2008. V. 39. N 4. P. 10-12.

23. Chen Ye, Chen Gang, Chen Liang. Review of studies on effects of molecular structure on azo dye microbial decolorization. J. Environm. Sci. Technol. 2011. V. 34. N 8. P. 65-69.

24. Nevsky A.V., Meshalkin V.P., Sharnin V.A. Analysis and Synthesis of Water Resource-Saving Chemical Processes. M.: Nauka. 2004. 212 p.

Поступила в редакиию 15.01.2018

Принята к опубликованию 16.03.2018

Received 15.01.2018

Accepted 16.03.2018 